Int. J. Dev. Biol. 58: 199-204 (2014)

doi: $10.1387 / \mathrm{ijdb} .140032 \mathrm{kc}$

\title{
Uterine natural killer cells as modulators of the maternal-fetal vasculature
}

\author{
BROOKE C. MATSON ${ }^{1}$ and KATHLEEN M. CARON ${ }^{*}, 1,2$ \\ ${ }^{1}$ Departments of Cell Biology \& Physiology and ${ }^{2}$ Genetics, University of North Carolina at Chapel Hill,
} North Carolina, USA

\begin{abstract}
Precise and local control of the innate immune system within the placenta is an essential component for achieving a normal and healthy pregnancy. One of the most abundant immune cells of the placenta is a subpopulation of natural killer (NK) cells that profusely populates the uterine decidua during early pregnancy. Uterine NK (uNK) cells and trophoblast cells of the placenta communicate both directly and indirectly to contribute to the critical process of spiral artery remodeling. Here, we discuss recent findings that expand our knowledge of uNK cell-trophoblast cell crosstalk and the important role it plays in the maternal vascular adaptation to pregnancy.
\end{abstract}

KEY WORDS: $\mathcal{N K}$ cell, trophoblast cell, placenta, spiral artery remodeling, preeclampsia

\section{Introduction}

Natural killer (NK) cells are lymphocytes belonging to the innate immune system that attack virally-infected cells and tumor cells via exocytosis of perforin- and granzyme-containing granules. In females, there are two populations of NK cells: peripheral blood (pb) NK cells and decidual (d) or uterine (u) NK cells. Both NK cell populations are capable of cytotoxicity and cytokine secretion. However, pbNK cells are primarily lytic cells, while uNK cells are primarily cytokine and chemokine producers.

A dramatic expansion of UNK cells occurs during early pregnancy, populating two adjacent areas of the implantation site, the decidua basalis (DB) and the mesometrial lymphoid aggregate of pregnancy (MLAp). Proliferation continues until mid-pregnancy, at which point uNK cells comprise up to $70 \%$ of immune cells present in the decidua, the progesterone-altered endometrium of the uterus that supports the conceptus (Bulmer et al., 2010). uNK cell population size then declines until the end of pregnancy.

Molecular characterization of uNK cells has led to the identification of subpopulations of uNK cells in the decidua. Mouse uNK cells, previously identified by periodic acid Schiff (PAS) staining, are also currently identified by Dolichos biflorus agglutinin (DBA) lectin staining (Paffaro et al., 2003). PAS and DBA lectin staining defines two subpopulations of $u$ NK cells: $\mathrm{PAS}^{+} \mathrm{DBA}^{-}$and $\mathrm{PAS} \mathrm{S}^{+} \mathrm{DBA}^{+}$ cells, which exhibit different gene expression profiles (Chen et al., 2012, Zhang et al., 2011). While PAS is a pan-uNK cell marker, DBA lectin detects the subpopulation of cells that expands during pregnancy, as $90 \%$ of uNK cells at mid-gestation are $\mathrm{DBA}^{+}$(Zhang et al., 2011).
In contrast to the mouse, human uNK cells are identified by their CD56 CD16 signature. The vast majority of uNK cells are CD56 bright CD16-, and pbNK cells are typically CD56 ${ }^{\mathrm{dim}}$ CD16+. Interestingly, while both subpopulations are present in the decidua, the proportion of these two subsets can shift to favor cytotoxic CD56 ${ }^{\mathrm{dim}}$ CD16 ${ }^{+}$ cells in the presence of infectious agents like cytomegalovirus (Siewiera et al., 2013) and Toxoplasma gondii (Xu et al., 2013a), both common intrauterine infections that cause severe birth defects.

Despite belonging to the immune system, uNK cells' primary contributions to the developing pregnancy are not immune in nature. Rather, uNK cell-secreted cytokines and chemokines communicate with fetal trophoblast cells of the placenta (Hanna et al., 2006); these two cell types act in concert to remodel spiral arteries, conduits of blood from the uterus to the placental bed and growing fetus (Smith et al., 2009). The importance of this process is stressed by the association of insufficient spiral artery remodeling with several diseases of pregnancy, such as fetal growth restriction (FGR) and preeclampsia. Here, we briefly review aspects of uNK cell-trophoblast cell crosstalk and their role in spiral artery remodeling and the maintenance of pregnancy, as summarized in Fig. 1.

\section{Signals promoting differentiation of UNK cells}

Little is known about uNK cell precursors and the source of the expanded uNK cell population during pregnancy. However, there

\footnotetext{
Abbreviations used in this paper: AM, adrenomedullin; DBA, Dolichos biflorus agglutinin; FGR, fetal growth restriction; HLA, human leukocyte antigen; KIR, killer cell Ig-like receptor; MMP, matrix metalloproteinase; uNK, uterine natural killer.
}

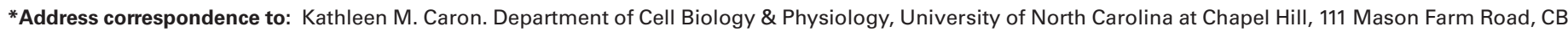
\#7545, 6312 MBRB, Chapel Hill, North Carolina, 27599, USA.Tel: +1-(919) 966-5193. Fax: +1-(919) 966-6923. Email: kathleen_caron@med.unc.edu
} 
is evidence to suggest that the majority of uNK cell precursors originate from outside the uterus. In the early 2000s, Croy and colleagues were unable to detect differentiated UNK cells in NK cell-deficient animals engrafted with parts of wild type uteri, suggesting that uNK cell precursors are extra-uterine (Chantakru et al., 2002). More recently, analysis of changes in uNK cell surface markers during pregnancy suggest that uNK cells endogenous to the uterus decline between gestation day (gd) 0 and gd6, perhaps because their cytotoxicity would be lethal to the foreign conceptus (Takashima et al., 2013). Therefore, the endogenous uNK cell population may be less critical for the maintenance of pregnancy than uNK cells that differentiated from extra-uterine precursors.

Macrophage-derived interleukin-15 (IL-15) is a critical regulator of NK and uNK cell differentiation. It was first observed that the time course of IL-15 expression during pregnancy parallels that of uNK cell granule contents (Ye et al., 1996). Soon thereafter, IL-15 I- animals were generated (Kennedy et al., 2000). IL-15 ${ }^{-/}$females lack uNK cells, MLAps, and spiral artery remodeling despite birthing litters of average size but slightly below-average weight (Ashkar et al., 2003, Barber and Pollard, 2003). Recent microarray analysis comparing $\mathrm{IL}-15^{-/}$and $\mathrm{IL}-15^{+/+}$animals did not detect differences in expression levels of genes involved in decidualization (Bany et al., 2012). Therefore, the finding of below-average weight pups born to $\mathrm{IL}-15^{-/}$dams cannot be explained by differences in decidualization and is likely due to the effect of IL-15 on uteroplacental circulation via stimulation of uNK cell differentiation.

Recent studies offer candidate regulators of IL-15 expression. For example, there is evidence that the transcription factor Runx3 acts together with other transcription factors to promote IL-15 expression (Levanon et al., 2014). However, there are also potentially indirect regulators of IL-15 expression. For example, a conditional knockout (cKO) of bone morphogenic protein receptor 2 (BMPR2) in the female reproductive system demonstrated decreased IL-15 expression (Nagashima etal., 2013). As may be expected, BMPR2 cKOs lacked uNK cells at implantation sites and exhibited defects in placentation.

In another animal model of placental underperfusion, heme oxygenase-1 ( $\mathrm{HO}-1$ ) heterozygotes and knockouts also downregulated IL-15 expression and exhibited fewer uNK cells in the DB and MLAp (Linzke et al., 2013). Similar to BMRP2 cKOs, Hmox $1^{\text {+l- dams }}$ demonstrated intrauterine growth restriction (IUGR), suggesting poor uteroplacental circulation. Interestingly, treatment with $\mathrm{CO}$, a byproduct of HO's heme metabolism, elevated uNK cell numbers, promoted spiral artery remodeling, and decreased the incidence of fetal death. However, CO treatment did not elevate IL-15 levels. In an attempt to explain why IL-15 is downregulated in Hmox $1^{+-}$ and $\mathrm{Hmox} 1^{--}$animals, the authors suggest that $\mathrm{CO}$ may affect the activity of macrophages, a demonstrated source of IL-15 in the pregnant uterus (Ye et al., 1996). If true, this hypothesis could address the well-established, counterintuitive protection that smoking confers against preeclampsia. Altogether, these observations suggest potential indirect mechanisms of uNK cell differentiation via regulation of IL-15 expression.

\section{Direct interactions between uNK and trophoblast cells: KIRs and HLAs}

Differentiated uNK cells express activating and inhibitory cell surface receptors. Stimulation of these subtypes by trophoblast- expressed ligands, for example, determines the degree of uNK cell activity. Interestingly, the proportions of activating and inhibitory receptors may shift in the presence of a foreign pathogen to modify uNK cell activity and promote cytotoxicity (Xu et al., 2013b). Many of these uNK cell surface receptors belong to the killer cell Ig-like receptor (KIR) family. KIRA and B haplotypes preferentially express inhibitory and activating receptors, respectively, and bind to fetal trophoblast-expressed human leukocyte antigen C (HLA-C), a major histocompatibility complex (MHC) type I molecule.

Importantly, Moffett and colleagues demonstrated associations of certain KIR-HLA combinations, specifically KIRAA and HLA-C2, with diseases of pregnancy like preeclampsia and miscarriage (Hiby et al., 2008, Hiby et al., 2004). Binding of fetal HLA-C2 to the inhibitory receptor KIR2DL1 in these women may predispose to preeclampsia and other placental disorders via insufficient uNK cell activation (Hiby et al., 2004). In contrast, KIR B women preferentially express uNK cell activating receptors. In these women, HLA-C2 likely binds to the activating receptor KIR2DS1, protecting women against these diseases by activating uNK cells and stimulating trophoblast invasion (Hiby et al., 2010, Hiby et al., 2004). Recent evidence that KIR2DS1 stimulates secretion of cytokines like granulocyte macrophage colony-stimulating factor (GM-CSF) by uNK cells and trophoblast migration supports this paradigm (Xiong et al., 2013).

While HLA-C has attracted attention for its disease associations, trophoblast cells express HLAs other than HLA-C. Specifically, they also express HLA-E and HLA-G. HLA-E binds to CD94/NKG2A, an inhibitory receptor on uNK cells (King et al., 2000), and HLA-G binds to leukocyte immunoglobulin-like receptors (LILRs) on uNK cells (Apps et al., 2007). However, HLA-G also binds to a KIR, CD158d/KIR2DL4, which is expressed in endosomes, not on the uNK cell surface like other KIRs (Rajagopalan, 2010). Binding of HLA-G to KIR2DL4 activates downstream pathways that confer a senescent phenotype on the uNK cell (Rajagopalan and Long, 2012). Supernatants from KIR2DL4-stimulated uNK cells enhance the permeability and angiogenic capacity of human ubilical vein endothelial cells (HUVECs). It is easy, therefore, to imagine a role for uNK cells in placental vascular remodeling via HLA-G stimulation of KIR2DL4.

Despite the attention paid to the consequences of HLA-KIR interactions, there is likely a role for non-KIR uNK cell receptors that bind to non-HLA ligands. Specifically, the aryl hydrocarbon receptor (AHR) is expressed by DBA- uNK cells and may be important for the proliferation of this oft-ignored uNK cell subset (Felker et al., 2013). While $\mathrm{Ahr}^{--}$implantation sites demonstrated wild type levels of total uNK cells, $\mathrm{DBA}^{+}$cells were smaller, and DBA- cells were fewer in number (Felker et al., 2013). Ahr ${ }^{-/}$animals also demonstrated insufficient spiral artery remodeling. Similarly, loss of natural cytotoxicity receptors (NCR), expressed by $\mathrm{DBA}^{+}$cells, didn't affect total uNK cell numbers but impaired uNK cell maturation and spiral artery remodeling (Felker et al., 2013). While the ligands for these receptors are unknown, they are clearly playing an important role in uNK cell maturation and activity, highlighting the importance of interactions outside the KIR-HLA axis.

\section{Trophoblast-derived factors affect uNK cell recruitment}

uNK cell-trophoblast cell crosstalk extends beyond contacts between cell surface proteins. For example, trophoblast-derived 
peptides of the calcitonin (CT)/calcitonin gene-related peptide (CGRP) family are involved in maintaining proper placental perfusion, possibly by communicating with uNK cells. The clearest link between a CGRP family member, uNK cells, and spiral artery remodeling is adrenomedullin (AM).

Levels of AM, an anti-inflammatory vasodilator, are physiologically elevated in normal pregnancy (Gibbons et al., 2007) but altered in adverse pregnancy outcomes (Lenhart and Caron, 2012). Polymorphisms in the AM gene are associated with birth weight, glycemic regulation, and preeclampsia (Lenhart et al., 2013). AM localizes to implantation sites and is expressed by the uterine epithelium and fetal trophoblast cells (Li et al., 2006). Fetal trophoblast cells also express the AM receptor, calcitonin receptor-like receptor (CLR) (Tsatsaris et al., 2002). Interestingly, $\mathrm{AM}^{+/-}$females are less fertile due to diminished uterine receptivity (Li et al., 2008), and pups born to $\mathrm{AM}^{+/-}$females are more likely to demonstrate FGR (Li et al., 2006). Altogether, these data suggest a role for maternal $\mathrm{AM}$ in implantation and placentation.

However, $\mathrm{AM}^{-/}$embryos are more likely to exhibit FGR than $\mathrm{AM}^{+/-}$or $\mathrm{AM}^{+/+}$embryos, suggesting a role for fetal-derived $\mathrm{AM}$ in placentation. $\mathrm{AM}^{-/-}$placentas demonstrate fewer uNK cells and retention of vascular smooth muscle cells lining spiral arteries compared to $\mathrm{AM}^{+/+}$placentas (Li et al., 2013). Concordantly, placentas from $A M^{\text {hi/hi }}$ pregnant females, a gene-targeted animal model of AM overexpression, exhibit $30 \%$ more uNK cells than $\mathrm{AM}^{+/+}$placentas and upregulate cytokine, chemokine, and matrix metalloproteinase (MMP) expression. In vitro, uNK cell-conditioned media supplemented with AM promotes apoptosis of vascular smooth muscle cells, supporting the emerging role for uNK cells in spiral artery remodeling (Li et al., 2013). It remains to be seen whether AMmediated uNK cell recruitment and activity is dosage-dependent.

Like AM, adrenomedullin 2 (AM2), also known as intermedin, is physiologically elevated during pregnancy (Chauhan et al., 2007). Administration of an AM2 antagonist causes FGR, highlighting the importance of AM2 in a healthy pregnancy (Chauhan et al., 2006).
AM2 is expressed by trophoblast cells and stimulates their invasion via the mitogen-activated protein kinase (MAPK) signaling pathway (Chauhan et al., 2011, Havemann et al., 2013). AM2 also dose-dependently stimulates HLA-G expression in trophoblasts cells, possibly stimulating KIR2DL4 signaling on uNK cells that could then acquire a senescent phenotype and increase vascular permeability and angiogenesis (Chauhan et al., 2011, Rajagopalan and Long, 2012). It is appealing to test whether AM2 dosage correlates with $\mathrm{uNK}$ cell recruitment to the decidua and consequent spiral artery remodeling.

Other CGRP family members also appear to modulate the uteroplacental circulation. For example, CGRP affects blood pressure regulation at the maternal-fetal interface, and its levels are altered in pregnancy-induced hypertension and preeclampsia (Dong et al., 2005, Dong et al., 2004, Fei et al., 2012, Gangula et al., 2003, Knerr et al., 2002). However, CGRPs' effects on uNK cell recruitment and activity remain to be elucidated.

As may be expected, there are trophoblast-derived factors outside the CGRPfamily that communicate with uNK cells. For example, thrombopoietin (TPO) and its receptor c-Mpl are expressed by uNK cells and trophoblast cells and act in concert to stimulate the proliferation and migration of these cell types via the JAK/STAT pathway (Segerer et al., 2013). As we come to understand more about uNK cell-trophoblast cell crosstalk, we imagine that other trophoblast-derived factors will come to light as important effectors of uNK cell recruitment and activation.

\section{uNK cell-derived factors promote placental vascular remodeling}

uNK cells generate an array of angiogenic growth factors, cytokines, and chemokines in different proportions at different times of pregnancy, suggesting a continuous and evolving role for uNK cells as pregnancy progresses. Here, we briefly discuss several examples of uNK cell-derived factors, acknowledging that there

Fig. 1. A combination of direct and indirect interactions between uterine natural killer cells (uNKs) and trophoblast cells in the decidua influences spiral artery remodeling.

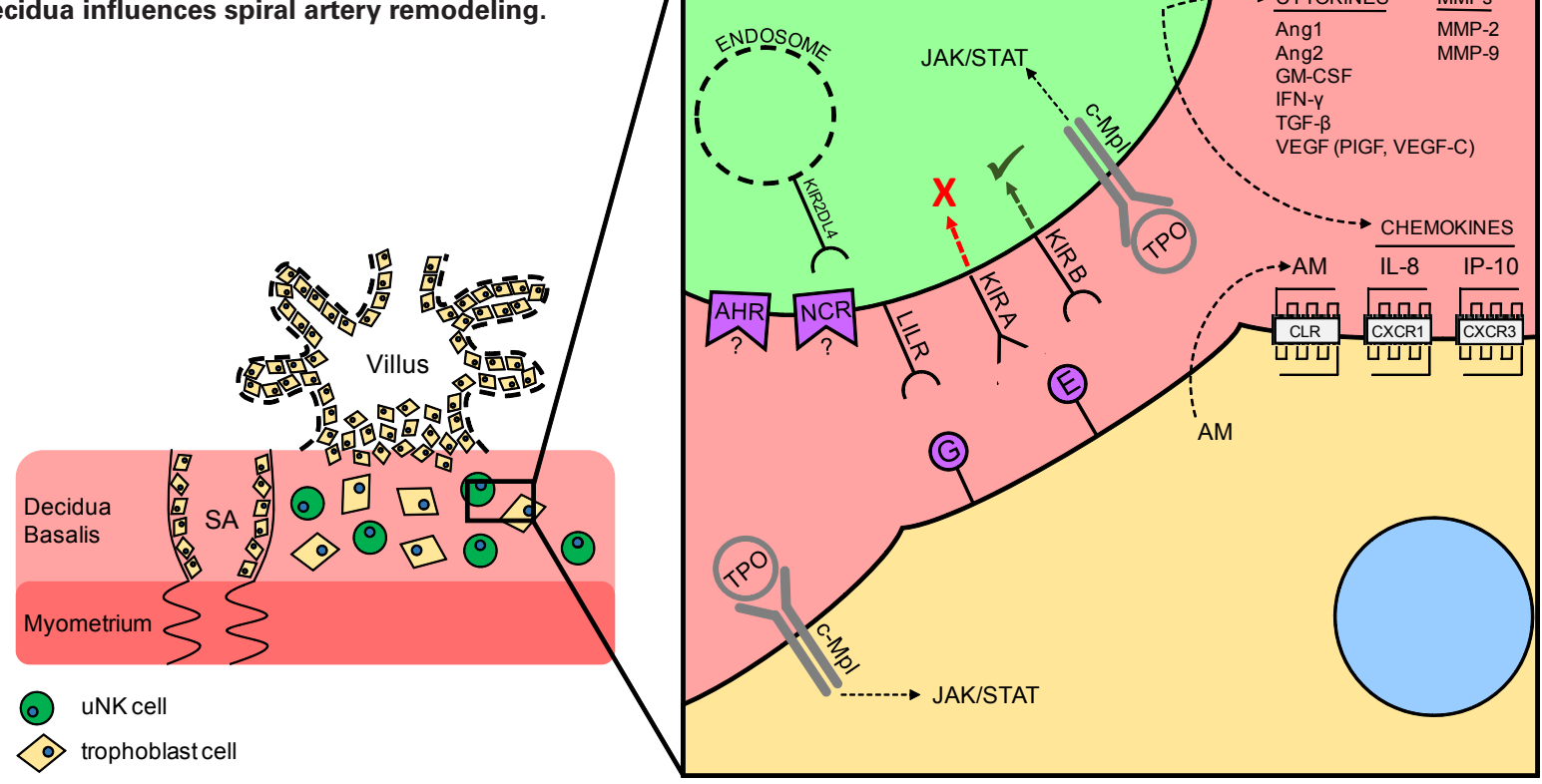


are many others we do not address.

Angiopoietin (Ang) 1 and 2, transforming growth factor $\beta$ (TGF$\beta$ ), and vascular endothelial growth factor (VEGF) are several examples of uNK cell-secreted angiogenic factors (Lash et al., 2006). Placental growth factor (PIGF) belongs to the VEGF family and has emerged as a potential biomarker for preeclampsia, emphasizing the significance of these angiogenic factors in proper uteroplacental circulation (Chappell et al., 2013, Levine et al., 2004). VEGF-C also belongs to the VEGF family and may assume an additional role in protecting trophoblast cells from uNK cell cytotoxicity (Kalkunte et al., 2009). The concentration of these factors decreases in the decidua as pregnancy progresses, suggesting that they may be irrelevant after spiral artery remodeling concludes (Lash et al., 2006).

Interferon-gamma (IFN- $\gamma$ ) is a uNK cell-secreted cytokine that has arguably attracted the most attention in the literature; it is necessary and sufficient for spiral artery remodeling (Ashkar and Croy, 2001). IFN- $\gamma$ inhibits trophoblast invasion by promoting apoptosis of trophoblast cells and altering protease levels, keeping trophoblast invasion in check (Lash et al., 2006). Perhaps counterintuitively, uNK cells from preeclamptic women secrete less IFN- $\gamma$ than uNK cells from normotensive controls (Zhou et al., 2013).

uNK cells also produce a variety of chemokines, including interleukin-8 (IL-8) and interferon-inducible protein-10 (IP-10). Receptors for these two chemokines, CXCR1 and CXCR3, respectively, are expressed on the trophoblast cell surface, substantiating uNK cells' candidacy as potent regulators of trophoblast invasion (Hanna et al., 2006). However, IL-8 and IP-10 presence in UNK cell-conditioned media (CM) isn't different between pregnancies with normal and high uterine artery Doppler resistance indices (RIs) (Wallace et al., 2013). To generate uNK cell CM, the authors plated equal densities of uNK cells from the different pregnancies, which could explain this finding. uNK cell chemokine secretion could very well be equivalent cell to cell, but the two types of pregnancies may have different population sizes of uNK cells. CM from these pregnancies did differ in extracellular signal-regulated kinase (ERK) and Akt pathway activation, which are critical for trophoblast invasion. Therefore, it is possible that uNK cells of these two types of pregnancies differentially express chemokines other than the ones examined in this study.

Finally, uNK cells are also sources of MMPs such as MMP-2 (Naruse et al., 2009). The previously mentioned peptide hormone AM stimulates MMP-9 secretion from uNK cells, triggering spiral artery smooth muscle cell apoptosis (Li et al., 2013). Altogether, this orchestra of signaling molecules coordinates the complex process of spiral artery remodeling to maintain a healthy pregnancy. Intriguingly, angiogenic growth factors and cytokines decrease in concentration when uNK cells and trophoblast cells are co-cultured, though the cell type from which these factors are derived in this co-culture is uncertain (Lash et al., 2011). No doubt additional signals will be identified that will further our understanding of uNK cell-trophoblast interactions.

\section{Conclusions}

In summary, the overall immune milieu of the placenta is an important determinant of the health and success of a pregnancy (Arck and Hecher, 2013, Erlebacher, 2013). Perturbations in this complex environment by lipopolysaccharide (LPS)-induced inflammation, for example, can cause abnormal placental vascular remodeling and phenotypes resembling FGR and preeclampsia (Cotechini et al., 2014). uNK cells dominate this immune landscape during early pregnancy and are important modulators of the maternalfetal vasculature. Generalized inflammatory changes triggered by obesity, for example, can cause under-recruitment of uNK cells to the decidua, which could explain why obesity elevates a patient's risk of pregnancy complications (Parker et al., 2013).

Certainly, there are other determinants of uNK cell density in the decidua during early pregnancy not discussed here, such as decidual cell-derived cytokines (Lockwood et al., 2013). However, it is likely that there are important effectors of spiral artery remodeling other than uNK cells (Charalambous et al., 2012); several studies suggest that uNK cells may be important only during a small time frame of this process. Ultimately, furthering our understanding of uNK-trophoblast cell interactions and their role in placental vascular remodeling will shed light on placentation disorders like FGR and preeclampsia and may potentially reveal new treatment modalities for these diseases.

\section{References}

APPS, R., GARDNER, L., SHARKEY, A.M., HOLMES, N. and MOFFETT, A. (2007) A homodimeric complex of HLA-G on normal trophoblast cells modulates antigenpresenting cells via LILRB1. Eur J Immunol 37: 1924-1937.

ARCK, P.C. and HECHER, K. (2013). Fetomaternal immune cross-talk and its consequences for maternal and offspring's health. Nat Med 19: 548-556.

ASHKAR, A.A., BLACK, G.P., WEI, Q., HE, H., LIANG, L., HEAD, J.R. and CROY, B.A (2003). Assessment of requirements for IL-15 and IFN regulatory factors in uterine NK cell differentiation and function during pregnancy. J Immunol 171: 2937-2944.

ASHKAR, A.A. and CROY, B.A. (2001). Functions of uterine natural killer cells are mediated by interferon gamma production during murine pregnancy. Semin Immunol 13: 235-241.

BANY, B.M., SCOTT, C.A. and ECKSTRUM, K.S. (2012). Analysis of uterine gene expression in interleukin-15 knockout mice reveals uterine natural killer cells do not play a major role in decidualization and associated angiogenesis. Reproduction 143: 359-375.

BARBER, E.M. and POLLARD, J.W. (2003). The uterine NK cell population requires $\mathrm{IL}-15$ but these cells are not required for pregnancy nor the resolution of a Listeria monocytogenes infection. J Immunol 171: 37-46.

BULMER, J.N., WILLIAMS, P.J. and LASH, G.E. (2010). Immune cells in the placental bed. Int J Dev Biol 54: 281-294.

CHANTAKRU, S., MILLER, C., ROACH, L.E., KUZIEL, W.A., MAEDA, N., WANG, W.C., EVANS, S.S. and CROY, B.A. (2002). Contributions from self-renewal and trafficking to the uterine NK cell population of early pregnancy. J Immunol 168:22-28.

CHAPPELL, L.C., DUCKWORTH, S., SEED, P.T., GRIFFIN, M., MYERS, J., MACKILLOP, L., SIMPSON, N., WAUGH, J., ANUMBA, D., KENNY, L.C. et al., (2013). Diagnostic accuracy of placental growth factor in women with suspected preeclampsia: a prospective multicenter study. Circulation 128: 2121-2131.

CHARALAMBOUS, F., ELIA, A. and GEORGIADES, P. (2012). Decidual spiral artery remodeling during early post-implantation period in mice: investigation of associations with decidual uNK cells and invasive trophoblast. Biochem Biophys Res Commun 417: 847-852.

CHAUHAN, M., BALAKRISHNAN, M., YALLAMPALLI, U., ENDSLEY, J., HANKINS, G.D., THEILER, R. and YALLAMPALLI, C. (2011). Adrenomedullin 2/intermedin regulates HLA-G in human trophoblasts. Biol Reprod 85: 1232-1239.

CHAUHAN, M., ROSS, G.R., YALLAMPALLI, U. and YALLAMPALLI, C. (2007) Adrenomedullin-2, a novel calcitonin/calcitonin-gene-related peptide family peptide, relaxes rat mesenteric artery: influence of pregnancy. Endocrinology 148: 1727-1735.

CHAUHAN, M., YALLAMPALLI, U., REED, L. and YALLAMPALLI, C. (2006). Adrenomedullin 2 antagonist infusion to rats during midgestation causes fetoplacental growth restriction through apoptosis. Biol Reprod 75: 940-947. 
CHEN, Z., ZHANG, J., HATTA, K., LIMA, P.D., YADI, H., COLUCCI, F., YAMADA, A.T. and CROY, B.A. (2012). DBA-lectin reactivity defines mouse uterine natural killer cell subsets with biased gene expression. Biol Reprod 87: 81.

COTECHINI, T., KOMISARENKO, M., SPEROU, A., MACDONALD-GOODFELLOW, S., ADAMS, M.A. and GRAHAM, C.H. (2014). Inflammation in rat pregnancy inhibits spiral artery remodeling leading to fetal growth restriction and features of preeclampsia. J Exp Med 211: 165-179.

DONG, Y.L., GREEN, K.E., VEGIRAGU, S., HANKINS, G.D., MARTIN, E., CHAUHAN, M., THOTA, C. and YALLAMPALLI, C. (2005). Evidence for decreased calcitonin gene-related peptide (CGRP) receptors and compromised responsiveness to CGRP of fetoplacental vessels in preeclamptic pregnancies. J Clin Endocrinol Metab 90: 2336-2343.

DONG, Y.L., VEGIRAJU, S., CHAUHAN, M., GANGULA, P.R., HANKINS, G.D., GOODRUM, L. and YALLAMPALLI, C. (2004). Involvement of calcitonin generelated peptide in control of human fetoplacental vascular tone. Am J Physiol Heart Circ Physiol 286: H230-H239.

ERLEBACHER, A. (2013). Immunology of the maternal-fetal interface. Annu Rev Immunol 31: 387-411.

FEI, X., HONGXIANG, Z., QI, C. and DAOZHEN, C. (2012). Maternal plasma levels of endothelial dysfunction mediators including AM, CGRP, sICAM-1 and tHcy in pre-eclampsia. Adv Clin Exp Med 21: 573-579.

FELKER, A.M., CHEN, Z., FOSTER, W.G. and CROY, B.A. (2013). Receptors for non-MHC ligands contribute to uterine natural killer cell activation during pregnancy in mice. Placenta 34: 757-764.

GANGULA, P.R., THOTA, C., WIMALAWANSA, S.J., BUKOSKI, R.D. and YALLAMPALLI, C. (2003). Mechanisms involved in calcitonin gene-related Peptide-induced relaxation in pregnant rat uterine artery. Biol Reprod 69: 1635-1641.

GIBBONS, C., DACKOR, R., DUNWORTH, W., FRITZ-SIX, K. and CARON, K.M. (2007). Receptor activity-modifying proteins: RAMPing up adrenomedullin signaling. Mol Endocrinol 21: 783-796.

HANNA, J., GOLDMAN-WOHL, D., HAMANI, Y., AVRAHAM, I., GREENFIELD, C., NATANSON-YARON, S., PRUS, D., COHEN-DANIEL, L., ARNON, T.I., MANASTER, I. et al., (2006). Decidual NK cells regulate key developmental processes at the human fetal-maternal interface. Nat Med 12: 1065-1074.

HAVEMANN, D., BALAKRISHNAN, M., BORAHAY, M., THEILER, R., JENNINGS, K., ENDSLEY, J., PHELPS, J., HANKINS, G.D., YALLAMPALLI, C. and CHAUHAN, M. (2013). Intermedin/adrenomedullin 2 is associated with implantation and placentation via trophoblast invasion in human pregnancy. J Clin Endocrinol Metab 98: 695-703.

HIBY, S.E., APPS, R., SHARKEY, A.M., FARRELL, L.E., GARDNER, L., MULDER, A., CLAAS, F.H., WALKER, J.J., REDMAN, C.W., MORGAN, L. et al., (2010). Maternal activating KIRs protect against human reproductive failure mediated by fetal HLA-C2. J Clin Invest 120: 4102-4110.

HIBY, S.E., REGAN, L., LO, W., FARRELL, L., CARRINGTON, M. and MOFFETT, A. (2008). Association of maternal killer-cell immunoglobulin-like receptors and parental HLA-C genotypes with recurrent miscarriage. Human Reproduction 23: 972-976.

HIBY, S.E., WALKER, J.J., O'SHAUGHNESSYK, M., REDMAN, C.W., CARRINGTON, M., TROWSDALE, J. and MOFFETT, A. (2004). Combinations of maternal KIR and fetal HLA-C genes influence the risk of preeclampsia and reproductive success. J Exp Med 200: 957-965.

KALKUNTE, S.S., MSELLE, T.F., NORRIS, W.E., WIRA, C.R., SENTMAN, C.L. and SHARMA, S. (2009). Vascular endothelial growth factor $C$ facilitates immune tolerance and endovascular activity of human uterine NK cells at the maternalfetal interface. J Immunol 182: 4085-4092.

KENNEDY, M.K., GLACCUM, M., BROWN, S.N., BUTZ, E.A., VINEY, J.L., EMBERS, M., MATSUKI, N., CHARRIER, K., SEDGER, L., WILLIS, C.R. et al., (2000). Reversible defects in natural killer and memory CD8 T cell lineages in interleukin 15-deficient mice. J Exp Med 191: 771-780.

KING, A., ALLAN, D.S., BOWEN, M., POWIS, S.J., JOSEPH, S., VERMA, S., HIBY, S.E., MCMICHAEL, A.J., LOKE, Y.W. and BRAUD, V.M. (2000). HLA-E is expressed on trophoblast and interacts with CD94/NKG2 receptors on decidual NK cells. Eur J Immunol 30: 1623-1631.

KNERR, I., DACHERT, C., BEINDER, E., METZLER, M., DOTSCH, J., REPP, R. and RASCHER, W. (2002). Adrenomedullin, calcitonin gene-related peptide and their receptors: evidence for a decreased placental mRNA content in preeclampsia and HELLP syndrome. Eur J Obstet Gynecol Reprod Biol 101: 47-53.
LASH, G.E., NARUSE, K., ROBSON, A., INNES, B.A., SEARLE, R.F., ROBSON, S.C. and BULMER, J.N. (2011). Interaction between uterine natural killer cells and extravillous trophoblast cells: effect on cytokine and angiogenic growth factor production. Human Reproduction 26: 2289-2295.

LASH, G.E., SCHIESSL, B., KIRKLEY, M., INNES, B.A., COOPER, A., SEARLE, R.F., ROBSON, S.C. and BULMER, J.N. (2006). Expression of angiogenic growth factors by uterine natural killer cells during early pregnancy. J Leukoc Biol 80: 572-580.

LENHART, P.M. and CARON, K.M. (2012). Adrenomedullin and pregnancy: perspectives from animal models to humans. Trends Endocrinol Metab 23: 524-532.

LENHART, P.M., NGUYEN, T., WISE, A., CARON, K.M., HERRING, A.H. and STUEBE, A.M. (2013). Adrenomedullin signaling pathway polymorphisms and adverse pregnancy outcomes. Am J Perinatol 31: 327-334.

LEVANON, D., NEGREANU, V., LOTEM, J., BONE, K.R., BRENNER, O., LESHKOWITZ, D. and GRONER, Y. (2014). Runx3 regulates interleukin- 15 dependent natural killer cell activation. Mol Cell Biol 34: 1158-1169.

LEVINE, R.J., MAYNARD, S.E., QIAN, C., LIM, K.H., ENGLAND, L.J., YU, K.F., SCHISTERMAN, E.F., THADHANI, R., SACHS, B.P., EPSTEIN, F.H. et al., (2004). Circulating angiogenic factors and the risk of preeclampsia. $N$ Engl $J$ Med 350: 672-683.

LI, M., SCHWERBROCK, N.M., LENHART, P.M., FRITZ-SIX, K.L., KADMIEL, M., CHRISTINE, K.S., KRAUS, D.M., ESPENSCHIED, S.T., WILLCOCKSON, H.H., MACK, C.P. et al., (2013). Fetal-derived adrenomedullin mediates the innate immune milieu of the placenta. J Clin Invest 123: 2408-2420.

LI, M., WU, Y. and CARON, K.M. (2008). Haploinsufficiency for adrenomedullin reduces pinopodes and diminishes uterine receptivity in mice. Biol Reprod 79: 1169-1175.

LI, M., YEE, D., MAGNUSON, T.R., SMITHIES, O. and CARON, K.M. (2006). Reduced maternal expression of adrenomedullin disrupts fertility, placentation, and fetal growth in mice. J Clin Invest 116: 2653-2662.

LINZKE, N., SCHUMACHER, A., WOIDACKI, K., CROY, B.A. and ZENCLUSSEN, A.C. (2013). Carbon monoxide promotes proliferation of uterine natural killer cells and remodeling of spiral arteries in pregnant hypertensive heme oxygenase-1 mutant mice. Hypertension 63: 580-588

LOCKWOOD, C.J., HUANG, S.J., CHEN, C.P., HUANG, Y., XU, J., FARAMARZI, S. KAYISLI, O., KAYISLI, U., KOOPMAN, L., SMEDTS, D. et al., (2013). Decidual cell regulation of natural killer cell-recruiting chemokines: implications for the pathogenesis and prediction of preeclampsia. Am J Pathol 183: 841-856.

NAGASHIMA, T., LI, Q., CLEMENTI, C., LYDON, J.P., DEMAYO, F.J. and MATZUK, M.M. (2013). BMPR2 is required for postimplantation uterine function and pregnancy maintenance. J Clin Invest 123: 2539-2550.

NARUSE, K., LASH, G.E., INNES, B.A., OTUN, H.A., SEARLE, R.F., ROBSON, S.C. and BULMER, J.N. (2009). Localization of matrix metalloproteinase (MMP)-2, MMP-9 and tissue inhibitors for MMPs (TIMPs) in uterine natural killer cells in early human pregnancy. Human Reproduction 24: 553-561.

PAFFARO, V.A., JR., BIZINOTTO, M.C., JOAZEIRO, P.P. and YAMADA, A.T. (2003). Subset classification of mouse uterine natural killer cells by DBA lectin reactivity. Placenta 24: 479-488.

PARKER, V.J., SOLANO, M.E., ARCK, P.C. and DOUGLAS, A.J. (2013). Diet-induced obesity may affect the uterine immune environment in early-mid pregnancy, reducing NK-cell activity and potentially compromising uterine vascularization. Int J Obes (Lond) 38: 766-774

RAJAGOPALAN, S. (2010). Endosomal signaling and a novel pathway defined by the natural killer receptor KIR2DL4 (CD158d). Traffic 11: 1381-1390.

RAJAGOPALAN, S. and LONG, E.O. (2012). Cellular senescence induced by CD158d reprograms natural killer cells to promote vascular remodeling. Proc Natl Acad Sci USA 109: 20596-20601.

SEGERER, S.E., MARTIGNONI, F., BOGDAN, A., MULLER, N., KAPP, M., DIETL, J., RIEGER, L. and KAMMERER, U. (2013). Thrombopoietin modulates the proliferation, migration and cytokine profile of decidual cell subsets during early gestation. Mol Hum Reprod 19: 361-368.

SIEWIERA, J., EL COSTA, H., TABIASCO, J., BERREBI, A., CARTRON, G. BOUTEILLER, P. and JABRANE-FERRAT, N. (2013). Human cytomegalovirus infection elicits new decidual natural killer cell effector functions. PLOS Pathog 9: e1003257.

SMITH, S.D., DUNK, C.E., APLIN, J.D., HARRIS, L.K. and JONES, R.L. (2009). Evidence for immune cell involvement in decidual spiral arteriole remodeling in early human pregnancy. Am J Pathol 174: 1959-1971. 
TAKASHIMA, A., ISHIKAWA, F., KUWABARA, T., TANAKA, Y., KINOSHITA, T., ITO, M. and KAKIUCHI, T. (2013). Uterine natural killer cells severely decrease in number at gestation day 6 in mice. Biol Reprod 89: 101.

TSATSARIS, V., TARRADE, A., MERVIEL, P., GAREL, J.M., SEGOND, N., JULLIENNE, A. and EVAIN-BRION, D. (2002). Calcitonin gene-related peptide (CGRP) and CGRP receptor expression at the human implantation site. J Clin Endocrinol Metab 87: 4383-4390.

WALLACE, A.E., HOST, A.J., WHITLEY, G.S. and CARTWRIGHT, J.E. (2013). Decidual natural killer cell interactions with trophoblasts are impaired in pregnancies at increased risk of preeclampsia. Am J Pathol 183: 1853-1861.

XIONG, S., SHARKEY, A.M., KENNEDY, P.R., GARDNER, L., FARRELL, L.E., CHAZARA, O., BAUER, J., HIBY, S.E., COLUCCI, F. and MOFFETT, A. (2013). Maternal uterine NK cell-activating receptor KIR2DS1 enhances placentation. $J$ Clin Invest 123: 4264-4272.
XU, X., FU, Q., ZHANG, Q., ZHAO, M., GAO, Z., LIU, X., LIU, Y. and HU, X. (2013a). Changes of human decidual natural killer cells cocultured with YFP-Toxoplasma gondii: implications for abnormal pregnancy. Fertil Steril 99: 427-432.

XU, X., ZHAO, M., LIU, X., JIANG, Y., ZHANG, H., ZHAI, X., ZHANG, L. and HU, $X .(2013 b)$. Toxoplasma gondii infection regulates the balance of activating and inhibitory receptors on decidual natural killer cells. PLoS One 8: e55432.

YE, W., ZHENG, L.M., YOUNG, J.D. and LIU, C.C. (1996). The involvement of interleukin (IL)-15 in regulating the differentiation of granulated metrial gland cells in mouse pregnant uterus. J Exp Med 184: 2405-2410.

ZHANG, J., CHEN, Z., SMITH, G.N. and CROY, B.A. (2011). Natural killer cell-triggered vascular transformation: maternal care before birth? Cell Mol Immunol 8: 1-11.

ZHOU, J., XIAO, X.M. and WU, Y.H. (2013). Expression of interferon-gamma in decidual natural killer cells from women with hypertensive disorder complicating pregnancy. J Obstet Gynaecol Res 40: 670-676. 


\section{Further Related Reading, published previously in the Int. J. Dev. Biol.}

Immunoregulatory molecules in human placentas: potential for diverse roles in pregnancy Joan S. Hunt, Judith L. Pace and Ryan M. Gill

Int. J. Dev. Biol. (2010) 54: 457-467

http://dx.doi.org/10.1387/ijdb.082831jh

\section{Local regulation of implantation at the human fetal-maternal interface}

Evdokia Dimitriadis, Guiying Nie, Natalie J. Hannan, Premila Paiva and Lois A. Salamonsen Int. J. Dev. Biol. (2010) 54: 313-322

http://dx.doi.org/10.1387/ijdb.082772ed

Critical growth factors and signalling pathways controlling human trophoblast invasion Martin Knöfler

Int. J. Dev. Biol. (2010) 54: 269-280

http://dx.doi.org/10.1387/ijdb.082769mk

Development and function of trophoblast giant cells in the rodent placenta

Dong $\mathrm{Hu}$ and James C. Cross

Int. J. Dev. Biol. (2010) 54: 341-354

http://dx.doi.org/10.1387/ijdb.082768dh

\section{Immune cells in the placental bed}

Judith N. Bulmer, Paula J. Williams and Gendie E. Lash

Int. J. Dev. Biol. (2010) 54: 281-294

http://dx.doi.org/10.1387/ijdb.082763jb

5 yr ISI Impact Factor $(2011)=2.959$
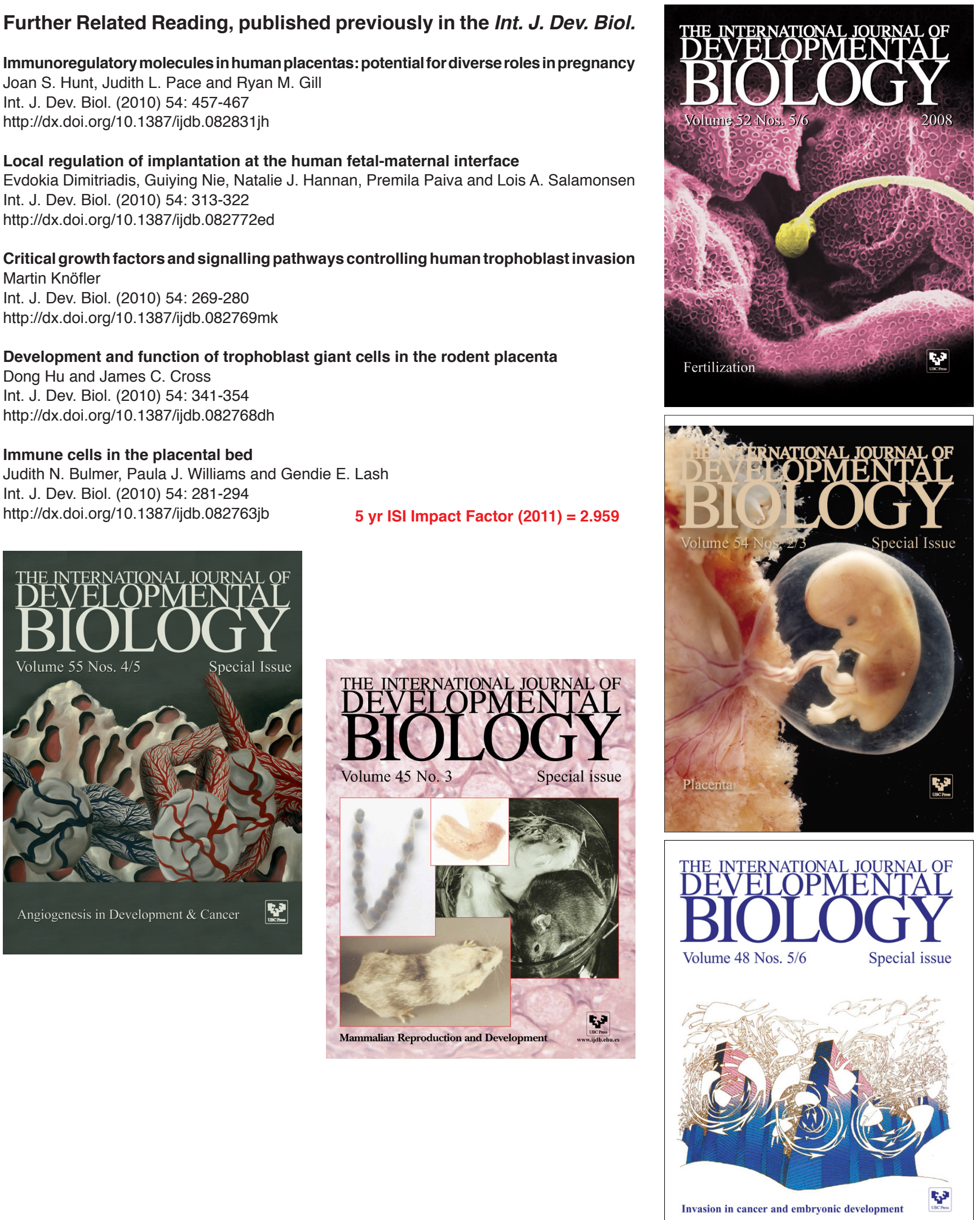